\title{
SOME NEW NEOTROPICAL NEUROPTEROID
} INSECTS

\author{
BY NATHAN BANKS
}

Museum of Comparative Zoölogy, Cambridge, Mass.

The following new species from the collection of the $\mathrm{Mu}$ seum of Comparative Zoölogy are mostly from Cuba and chiefly obtained in the past few years.

\section{Psocidæ}

\section{Compsocus gen. nov.}

Belongs to the Amphientominæ. Head moderately broad, bent down, clypeus fairly large, ocelli present, legs rather short, hind pair longer, tarsi of three joints, femora rather swollen, on hind tibia only a few spines on lower apical half. In hind wings the media is forked, and the axillary separate from anal. In fore wings the subcosta is long, curved, and ends in radius, forming a long cell; but one axillary vein, but this plainly forked toward base, axillary and anal end together; radius forked once, media twice; the cubital fork is near to margin and so almost forms an areola postica; surface of wing with many minute, short scales, some stout and rounded at tip, others longer and forked at tip, each kind in separate patches.

\section{Compsocus elegans sp, nov.}

Figure 4.

Black; antennæ very fine and thin; legs black, tarsi pale, hind basitarsus with dark band near middle. Wings black, with three hyaline white spots along hind margin, one at end of anal, one over lower branch of cubitus, and one over 
end of upper cubitus and reaching up to radial branch. On the surface of wing about 12 large silvery white spots; about five tending to form a row across near end of stigma, one of which is in end of stigma and extends beyond to next vein, one in the base of radial fork, two behind it, and one in the median fork; about middle of length are two more silvery spots, and before this an interrupted band from costa just beyond subcostal cell, and extending across radius, and two spots nearer to base; hind wings fumose, veins darker. In fore wings the short, rounded scales are in pale areas, the forked scales densely placed to form dark areas. Both wings iridescent.

Length $2.2 \mathrm{~mm}$.

From Barro Colorado Island, Panama, 23 June. A remarkably beautiful species.

\section{Hemipsocus pretiosus sp. nov.}

Figure 5.

Head dull yellowish, unmarked; antennæ also, likewise the thorax, abdomen blackish above, femora dark, tibia and tarsi pale; head, thorax and antennæ with moderately long, pale hair. Fore wings mostly brown; veins nearly black, the longitudinal veins with white spots, particularly prominent beyond the middle; two larger white spots on posterior margin just beyond the end of the cubital vein; veins with erect hairs arising from black spots; the vein bounding areola postica and the cross-vein above it are hyaline-white; hind wings grayish hyaline. Wings shorter than in $H$. roseus, but the venation is very similar, the fork of the median vein, however, reaches back to the cross-vein to areola postica or even onto the cross-vein.

Length of fore wing $2.2 \mathrm{~mm}$.

One from Soledad, Cuba, 18 February (Myers) and the other from Royal Palm Park, Florida (Blatchley). 
Thyrsopsocus pretiosus sp. nov.

Figure 3.

Head, thorax, and abdomen black, a pale V-mark on thoracic notum in front. Antennæ brown or black, with black hair on third joint, basal joints and base of four joint pale; legs black or brown, paler on apical part of tibia and basitarsus, middle tibia whole pale. Wings hyaline, with a large black spot occupying most of apical part as in the figure, containing three large pale areas; in front, one each side of the stigma, and one over most of the posterior cells; stigma dark at each end and behind to radius, yellowish through the middle; on basal part of wing two transverse black spots, and a longer oblique one above and into part of the cell. Veins dark, but end of discal cell and lower part of outer side, and the forking of radius yellow; hind wings hyaline, with dark veins.

Length of fore wing $6 \mathrm{~mm}$.

From Barro Colorado, Panama, 18, 23 July.

Thyrsopsocus bellulus sp. nov.

Figure 1.

Head pale yellowish brown; antennæ black, with black hair, basal two joints pale yellowish; thoracic notum pale, a dark band across connecting bases of fore wings; scutellum dark, with pale margin; abdomen dark above, near tip is a large yellowish spot each side, venter pale; legs pale, tips of tarsi dark. Wings hyaline, with mostly pale brown marks in apical part of wing as figured; the stigma yellow and the yellow extended back to radius; black marks at base of stigma, on each side along connection to radius, and in the posterior edge of cell, and two transverse marks in basal part of wing, the hinder one curved and extending toward base; veins mostly dark brown, the basal part of radius and some of media yellow, also most of stigmal vein; hind-wings hyaline, with dark veins.

Length of fore wing $6 \mathrm{~mm}$.

From Carmelina, Honduras, March, on orange (W. M. Mann). 


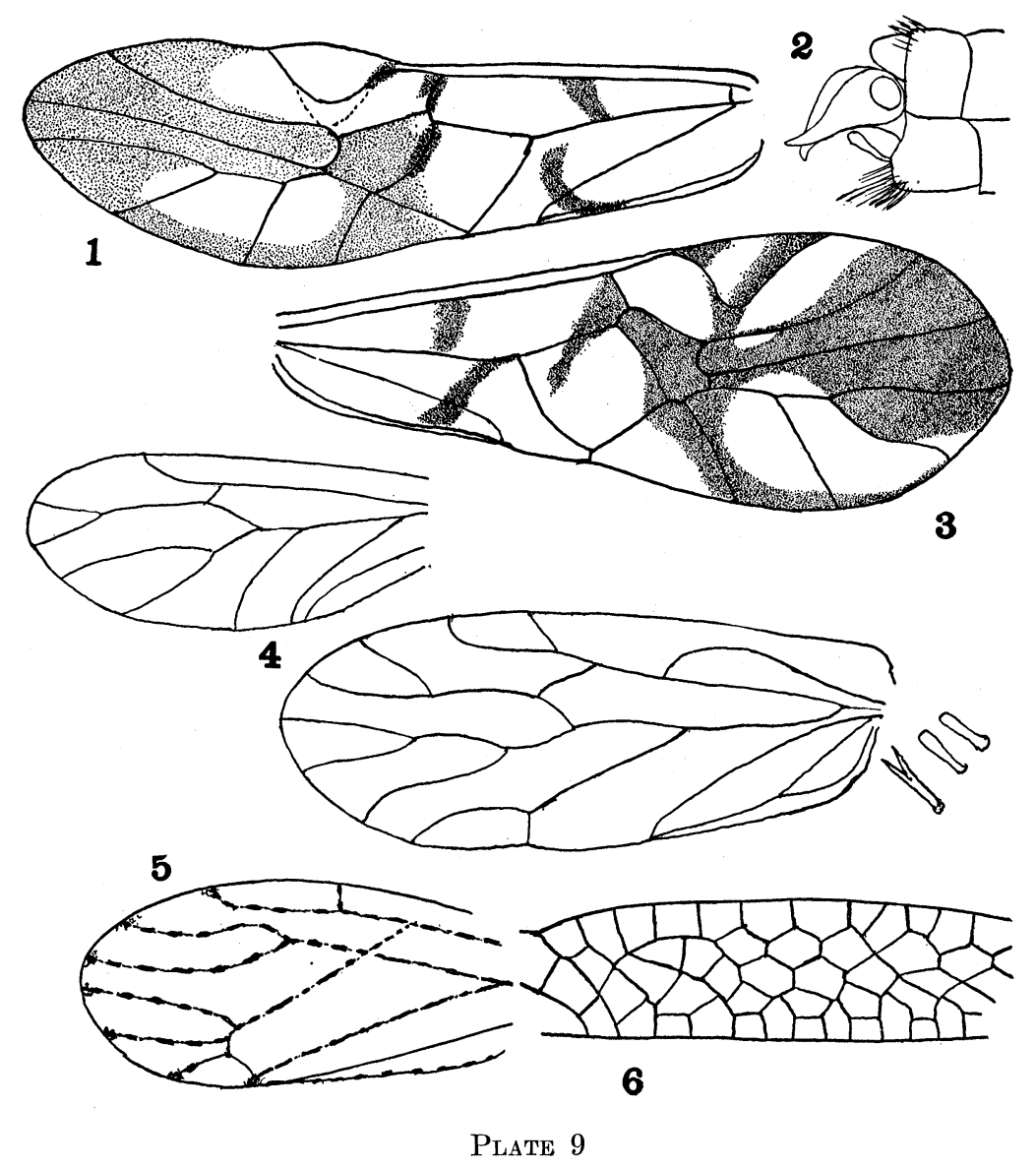

Banks-Neuropteroid Insects 


\section{Ephemeridæ}

Callibaetis completa sp. nov.

\& Body of the usual pale brownish, with many small dark dots, especially on the abdomen, beneath with larger, paired dots, above on abdomen the basal segments show a large dark spot in middle, tending to form a stripe; second joint of antennæ mostly dark brown; legs pale, the tarsal joints faintly dark at endings. Wings hyaline, a broad brown stripe along front margin, covering the first three veins, and on base a little more; this brown fills the costal area to base, and also at tip, it contains a number of transverse hyaline white marks, mostly over veins, very few of these pale spots in the apical fourth, behind the brown is fairly even. The veins are brown, and cross-veins also; there are a few cross-veins near tip, about eleven in a curved series from middle back to near base, before middle near middle of length are three cross-veins, and toward base three more.

Length fore wing $7.5 \mathrm{~mm}$.

From Soledad, Cuba, 20 June (G. Salt).

\section{Hemerobiidae}

\section{Hemerobius cubanus sp. nov.}

Head brownish yellow, no distinct marks; antennæ similar, but paler toward tips; thorax also similar, with long pale hair above; abdomen darker brown; legs pale, the tibiæ (especially of second and third pairs) swollen toward tip, the hind ones with a dark line on the hind edge of the swollen part.

Wings nearly hyaline, or faintly fumose; veins brown and pale in spots, and brown at origins, and from the brown spots are often extensions of brown out on the membrane; the gradates dark brown, and bordered with brown; stigma not distinct; the brown marks are closer and more distinct in the posterior basal part of wing; hind wing with some brown near tip over the cross-veins and also near base over the branches from anal vein. Wings about of shape of $H$. 
humuli, the costal area toward base a little broader; three branches to the radial sector, the last soon forked and again before the connection back to radius; about five inner and seven outer gradates, outer ones partly between forks, inner ones somewhat in pairs, the hind pair nearly interstitial.

Fore wing $6.5 \mathrm{~mm}$. long.

From Pico Turquino, Cuba, 5000 ft., 20 July; and Sierra Maestra, Cuba, 1100-1300 ft., 10-20 July, both collected by C. S. Bruner and C. H. Ballou.

Megalomus cubanus sp. nov.

Figure 2.

Head dull yellowish; antennæ pale brownish, basal joint yellowish; pronotum with about six or eight brown spots, rest of notum also largely dark; abdomen yellowish, as also legs. Wings faintly smoky, with yellowish venation, marked with black along the margin, groups of two or three dark dots; the gradates and an oblique streak up from end of anal nearly black, a brown spot at extreme base of wing, and often small dark dots at forking of veins; just beyond the first gradates there is a narrow pale stripe across wings; hind wing with dark before stigma, the basal part of radial sector and some apical dots dark. Costal area as wide as head plus the pronotum; five radial sectors, the fifth forked at first gradates and upper branch forked again before the second gradates. The median forked just before origin of second radial sector, cubital forked before first gradates.

Expanse $13 \mathrm{~mm}$.

From Soledad, Cuba, 6 March (J. E. Myers).

Has appearance of $M$. minor, but gradates not as oblique as in that species. 


\section{Coniopterygidæ}

\section{Coniopteryx marginalis sp. nov.}

Head yellowish brown; antennæ pale yellowish, legs also, a faint dark mark at tip of femur; mesonotum brown, with a rounded dark brown spot each side near base of wing, pleura nearly black; abdomen pale, dark at tip. Wings fumose, veins darker, most of the cross-veins bordered with hyaline white; along the outer and hind margin are about six dark spots, each between ends of veins; the nearest base is a large one just before the end of cubitus, the next a very small one just beyond the cubitus, then three large spots, in median fork, between media and radius, and in fork of radial sector, and then a small one just above end of radial sector. Hind wings unmarked; both wings mealy white. General shape and venation practically as figured for $C$. nivosa Enderlein.

Length $3 \mathrm{~mm}$.

From Sierra Maestra, Cuba, July 10-20, 1070 to $1350 \mathrm{ft.}$. C. S. Bruner and C. H. Ballou.

\section{Myrmeleonidæ}

Myrmeleon wrighti sp. nov.

Figure 6.

Head mostly black; lower face toward mouth, and the sides toward eyes pale; palpi and antennæ mostly black. Pronotum dull black, a trace of a pale median line in front, and the lateral margins narrowly pale, and a faint pale mark each side behind; rest of notum dark; pleura mostly dark. Femora black in apical half, middle femora almost wholly black, front and mid tibiæ with sub-basal and apical black marks, hind tibiæ black beneath and at tip; tarsi almost wholly black, bases of first and fifth joints only pale; bristles black. Abdomen dull black, a little pale each side at tip; hair short, black above, white below. Wings unmarked; venation interruptedly black and white; stigma pale. 
Pronotum much broader than long; first tarsal joint about one-half of fifth; spurs about equal to first joint. In the fore wing seven cross-veins before radial sector, in hind wings four, the first very oblique, about eight branches of the radial sector; in hind wing three or four branches of first anal vein; in fore wing about twelve connections between radial sector and radius before the stigma.

In fore wing (and also in hind pair) there is no definite line in cubital area parallel to cubitus as is present in nearly all species; there is the usual curved beginning of such a line, but it soon runs into the center of a series of diamond-shaped cells.

Length fore wing $34 \mathrm{~mm}$., width $7.3 \mathrm{~mm}$.; length hind wing $30 \mathrm{~mm}$., width $6 \mathrm{~mm}$.

From Cuba (Chas. Wright).

Readily separated from the common Cuban $M$. insertus by larger size, as well as peculiar structure of cubital area.

\section{Austroleon garciana sp. nov.}

Head pale, a large dark interantennal mark reaching up to vertex, a narrow dark band across above clypeus, last joint of palpi marked with dark, vertex with two conjoined dark spots above, each enclosing a pale spot behind, antennæ dark, faintly annulate with pale. Pronotum pale, two rounded dark spots in front, two streaks behind and a lateral dark stripe, margin with some long, curved, white bristles; meso- and metanotum much marked with dark, the scutelli with a median dark spot, pleura brown, with several pale spots, legs pale, dotted and spotted with brown, third and fourth tarsal joints almost wholly black, front coxa with several curved white macrochætæ, also a row above on the front femur; spurs equal to two tarsal joints. Abdomen dark, several segments show one or two pale spots or streaks each side above, hair above black on basal part, paler toward tip, venter with white hair.

Wings hyaline, veins dark, with pale spots, a rather distinct spot at the rhegma, radial sector in the hind wings almost wholly dark. Wings slender, much more so than in 
A. cubitalis Navas; venation generally similar to that species, two or three cross-veins in hind wings before radial sector, three in fore wings, about five branches to radial sector. The hind wing is so slender that the branches of cubitus are nearly simple, only a few forked and no crossveins between them as in A. cubitalis; the marginal hair is shorter than in cubitalis. Fore wing, length 16-18 mm., width 3.5-4 mm. Hind wing, length 15-17 mm., width 2.5-3 $\mathrm{mm}$. Abdomen 16-18 $\mathrm{mm}$. long.

From S. Barbara, 15 March, and N. Gerona, 1 March, Isle of Pines, Cuba, both by C. S. Bruner.

Differs from cubitalis Navas not only in smaller size, more slender wing, but also in pronotal marks, cubitalis having a single median mark behind; the spots on vertex also different. Both specimens lack the spots along cubitus seen in cubitalis.

\section{Explanation of Plate 9}

Fig. 1. Thyrsopsocus bellulus, fore wing.

Fig. 2. Megalomus cubanus, male genitalia.

Fig. 3. Thyrsopsocus pretiosus, fore wing.

Fig. 4. Compsocus elegans, hind and front wings and scales.

Fig. 5. Hemipsocus pretiosus, front wing.

Fig. 6. Myrmeleon wrighti, cubital area of wing. 

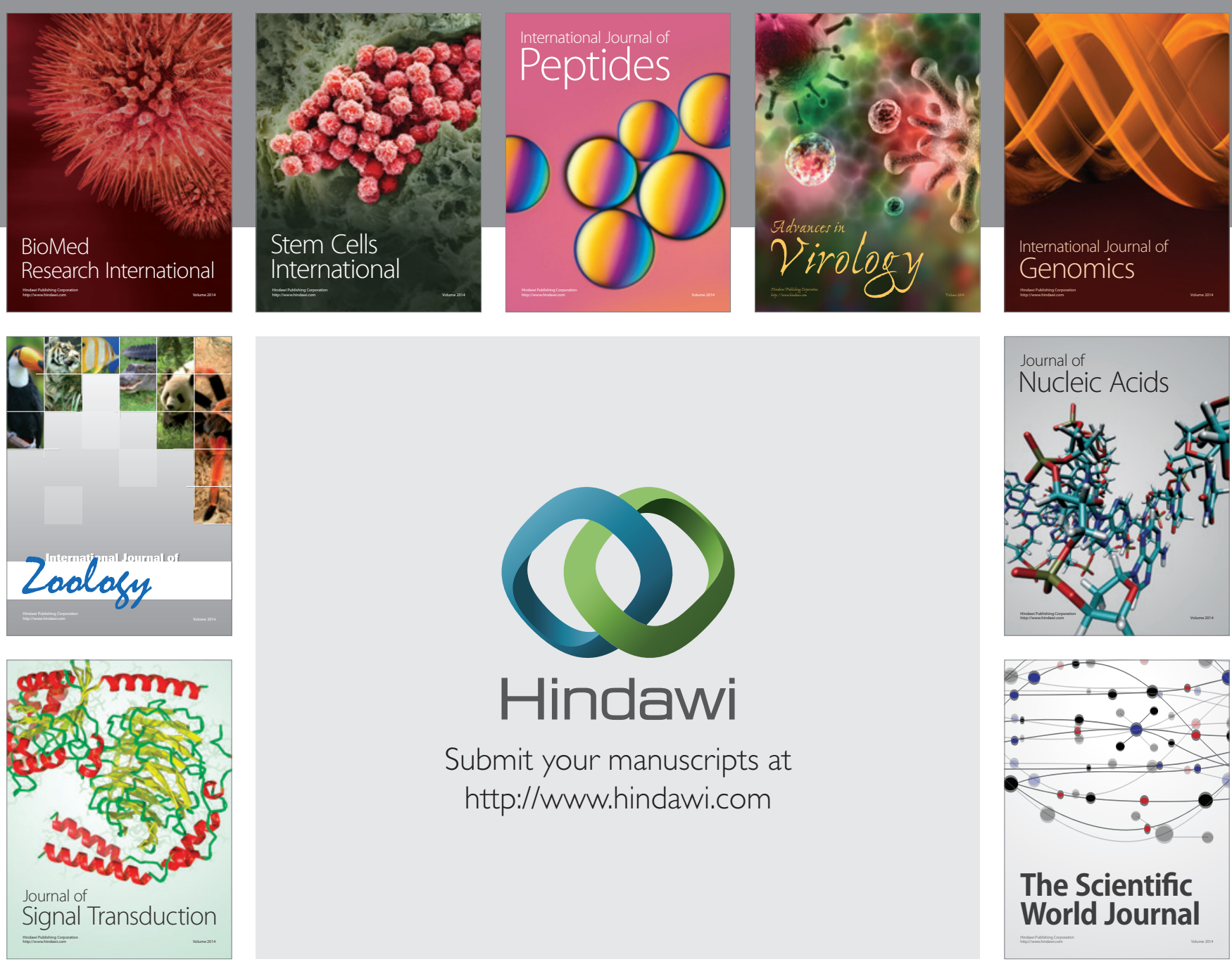

Submit your manuscripts at

http://www.hindawi.com
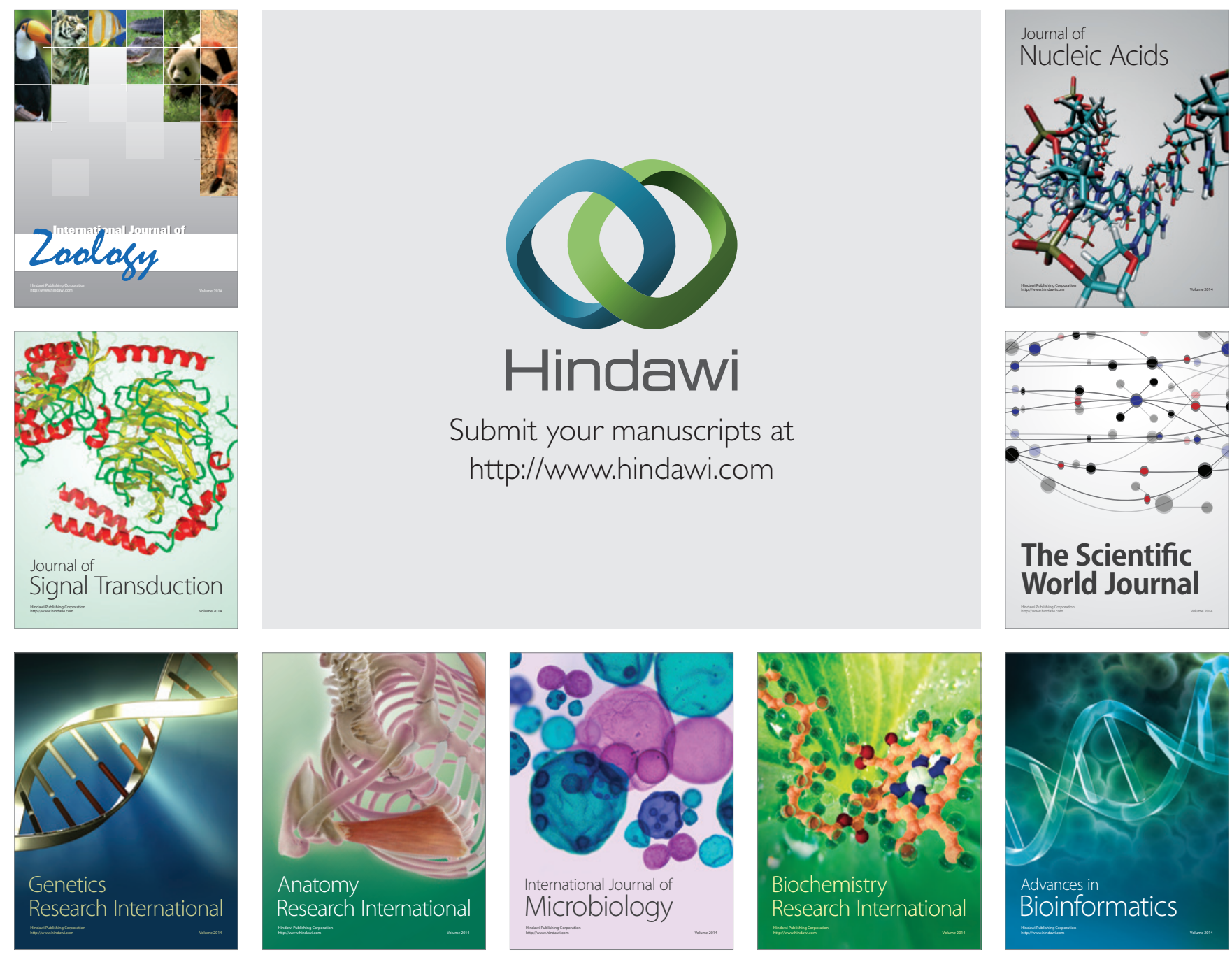

The Scientific World Journal
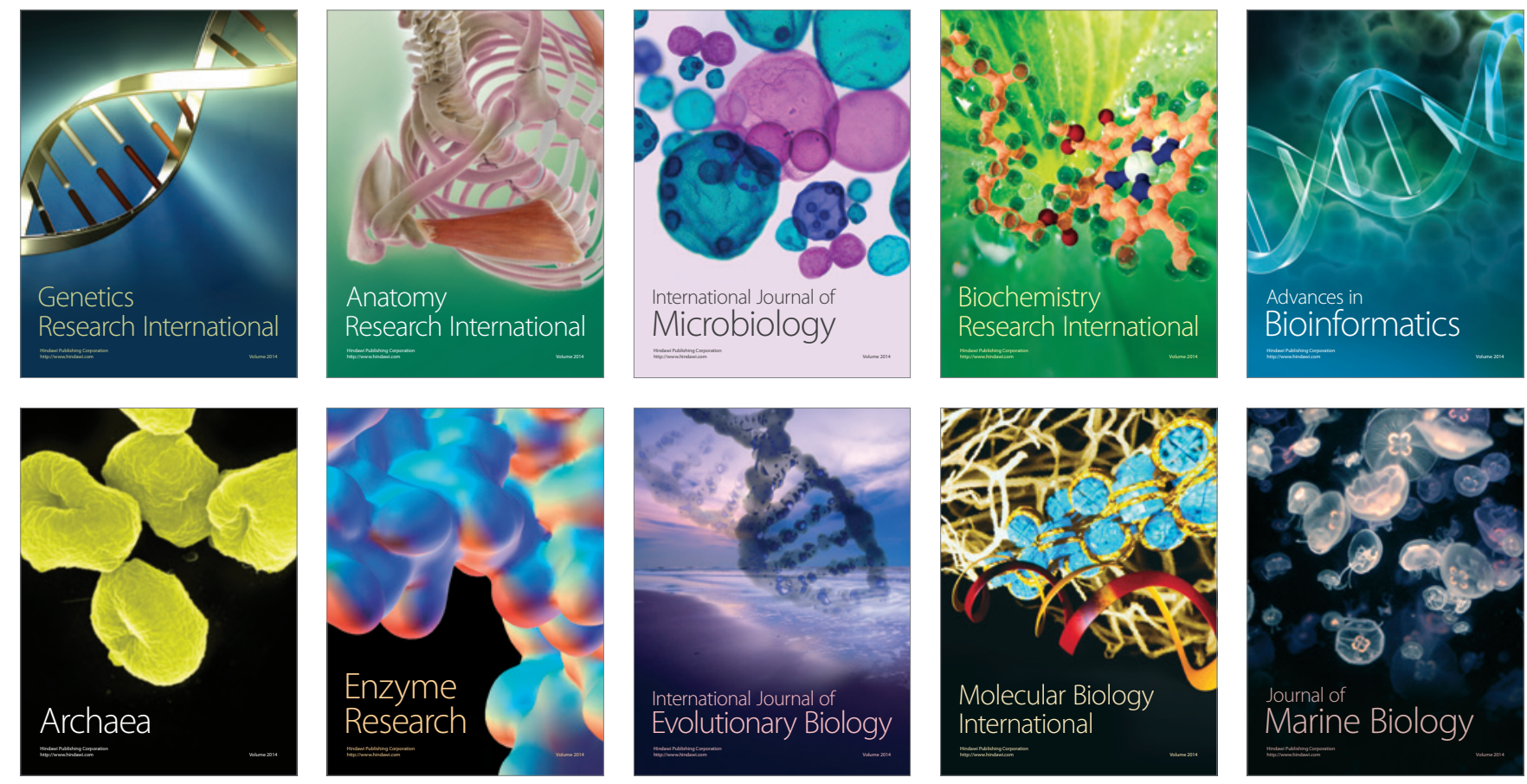